\title{
HISTÓRIA DA VIOLÊNCIA E SOCIEDADE BRASILEIRA
}

\section{VIOLENCE HISTORY AND BRAZILIAN SOCIETY}

DOI: http://dx.doi.org/10.15448/2178-3748.2018.1.24181

\author{
Jóice Bernaski \\ Mestre em História - UNICENTRO/PR \\ joicebernaski@yahoo.com.br \\ Hélio Sochodolak \\ Doutor em História e docente em História na UNICENTRO/PR \\ sochodo@gmail.com
}

\begin{abstract}
RESUMO: Desenvolvemos, no presente artigo, a hipótese de que a violência humana é histórica. Ela é um elemento que constrói e transforma as estruturas, as conjunturas e os cotidianos de distintas formas em várias temporalidades. Nesta perspectiva, abordaremos as características que a violência se circunscreveu em alguns períodos históricos, como nas sociedades Antigas, de fins da Idade Média, Antigo Regime, Modernidade e PósModernidade. No Brasil, a História foi marcada pelo constante uso da violência, tendo suas origens com o processo de colonização, primeiramente, na violenta política de subjugamento do indígena subsidiado pela ideologia da guerra justa, das jurisdições e dos aldeamentos. Com a prática da escravidão ocorrida durante séculos, que suprimiu a vida humana de maneira selvagem, e ainda de forma mais suave, com a política de subterfúgio empregada ao imigrante europeu, submetendo-o à escravidão simbólica. Essas práticas colonizatórias construíram um Brasil pautado na concentração de riquezas refletidas na desigualdade social que se proliferou no cotidiano, marcada, também, pelo uso constante da violência. Também abordaremos como os processos criminais são fontes profícuas para o entendimento da violência processada no Brasil. Essas discussões forçam a tese de que a violência é intrínseca à vida social, seja ela caracterizada de forma física ou simbólica.
\end{abstract}

PALAVRAS-CHAVE: Cotidiano. Sociedade. Violência.

ABSTRACT: We have developed in this article the hypothesis that human violence is historical. It is an element that builds and transforms structures, conjunctures and everyday life in different ways into various temporalities. In this perspective, we will examine the characteristics that violence has been limited to in some historical periods, as in Ancient societies, from the late Middle Ages, Old Regime, Modernity and Postmodernity. In Brazil history was marked by the constant use of violence, its origins with the colonization process, firstly, in the violent politics of subjugation of the indigenous, subsidized by the ideology of the just war, of the jurisdictions and of the villages. With the practice of slavery over the centuries that has suppressed human life wildly. And even softer, with the policy of subterfuge employed to the European immigrant, subjecting it to symbolic slavery. These colonial practices built a Brazil based on the concentration of riches reflected in social inequality that proliferate in daily life, also marked by the constant use of violence. We will also address the fact that criminal prosecutions are useful sources for the understanding of violence prosecuted in Brazil. These discussions force the thesis that violence is intrinsic to social life, be it characterized in a physical or symbolic way.

KEYWORDS: Daily. Society. Violence.

\section{INTRODUÇÃO}

O presente artigo parte do princípio de que a violência é histórica e também é um elemento que constrói e transforma as estruturas, as conjunturas e os cotidianos sociais em 
várias temporalidades, sendo, portanto, elemento propulsor, que dá sentido para a vida social. Ela cria e recria os espaços sociais, culturais, tradições, gêneros, classes, Estados, regimes políticos, etc, e está presente nos espaços mais minúsculos do cotidiano.

Assim, inspirados em René Girard (1990), primeiramente, abordaremos a violência e o seu controle nas sociedades antigas. Nesta perspectiva, investigamos como mecanismos ritualísticos e simbólicos podem ser identificados em outras sociedades e temporalidades. Discutiremos, também, o contexto do final da Idade Média, analisando a violência na formação e na consolidação do estado Absolutista, bem como na sua transição para o estado Moderno no século XIX. Para tanto, utilizamos como referenciais teóricos e historiográficos os autores Robert Muchembled (2012), Norbert Elias (1994) e Michel Foucault (1987).

$\mathrm{Na}$ segunda parte, analisaremos como a sociedade brasileira se configurou de forma violenta, especialmente nos XIX e XX, considerando como alguns brasileiros tratam da violência no país subsidiado por uma tipologia específica de documentos: os processos criminais. Por último, discutiremos quais são as características da violência no Brasil atual.

\section{VIOLÊNCIA NAS SOCIEDADES ANTIGAS}

A violência é tão antiga quanto todas as sociedades. Ela é resultado de certa soma de poder desferida contra alguém que, ao ser alvo de violência, procura revidar. Violência gera violência, produzindo sempre novos confrontos. Para Girard (1990, p. 10), "a violência é de todos e está em todos". A diferença é que ela se manifestou de forma distinta na história, sendo caracterizada de acordo com os padrões de cada época. Regra geral, a violência se combate com a introdução de uma dose maior da mesma, com o intuito de neutralizá-la.

Nas sociedades "sem poder judiciário instituído, cabe ao conjunto de interdições, sacrifícios e rituais desempenhar esse papel” (GIRARD, 1990, p. 9). Tais mecanismos regulatórios foram construídos, nas sociedades, ditando regras e comportamentos, que não poderiam ser quebrados sob o risco de punições sacrificais. Os sacrifícios eram ritualizados; de acordo com Girard (1990, p. 27), eles tinham “a função de apaziguar as violências intestinas e impedir a explosão de conflitos [...], incessantemente exorcizado pelo sacrifício de vítimas expiatórias", com o intuito de acalmar os instintos violentos dos espectadores. Em grande medida, os sacrifícios podem ser entendidos como formas punitivas que controlavam as sociedades com intuito de minimizar os conflitos, delitos e crimes.

Nem sempre os sacrifícios inibiam totalmente a violência, que voltava a se manifestar nas práticas sociais. Porém, as punições acalmavam os ânimos dos espectadores ao menos por 
algum tempo. Em situações-limite, a violência cotidiana era desestimulada com uma dose maior e espetacular de violência pelos rituais sacrificiais.

Rituais sacrificiais transmutados podem ser identificados de formas simbólicas em nossa sociedade, inclusive em rituais religiosos. Como exemplo, podemos citar as celebrações das missas da Igreja Católica, que relembram todo o processo sacrificial que Cristo passou até a sua morte na cruz. Nesse ritual, o pão representa o corpo, e o vinho, o sangue. Trata-se de um ritual expiatório reatualizado constantemente de maneira simbólica.

De forma diferenciada, embora análoga ao processo sacrificial das sociedades primitivas, podemos identificar vítimas expiatórias sendo conduzidas para sacrifícios. Por exemplo, no sistema político atual, em que os desvios de recursos públicos são inúmeros, apenas algumas pessoas são investigadas e punidas, exemplarmente, por cometerem esses delitos.

Quando um sujeito é punido por ato criminoso de desvio de recursos públicos, torna-se uma vítima expiatória, conduzida ao sacrifício simbólico, por meio do qual se apaziguam possíveis revoltas e descontentamentos. A população se sente lesada em ver seu dinheiro roubado, tendo em vista que vários serviços, como a educação e a saúde, estão em estado precário. Assim, periodicamente, é necessário que se punam algumas pessoas publicamente identificadas como corruptas, pacificando possíveis indignações.

As corrupções não são exterminadas com punições. Elas continuam a existir, e, em momentos posteriores, novas vítimas expiratórias serão escolhidas para serem punidas. A tese é de que, no momento em que a violência tende a sofrer uma escalada, "transbordando" seu nível "normal" por um dispositivo, ela deve ser "purificada" ritualmente, aliviando as tensões sociais.

\section{VIOLÊNCIA NA EUROPA NO FINAL DA IDADE MÉDIA}

No período do feudalismo, a população europeia era predominantemente camponesa. Nos caminhos que conectavam os feudos, circulavam os comerciantes, mas tais locais eram desprovidos de proteção e ofereciam perigos, como a presença de oportunistas e ladrões. Além disso, guerreiros constantemente travavam batalhas pelos campos.

As lutas resultaram no "aumento de suas posses de poder militar, uma posição de predominância sobre outros guerreiros" (ELIAS, 1994, p. 207). Dessa forma, "surgiram as Casas individuais, cujos governantes haviam conquistado em muitas batalhas" (ELIAS, 1994, p. 217). O enriquecimento e o encastelamento de algumas casas deram origem às cortes, que, 
paulatinamente, aumentaram os fluxos das pessoas que buscavam "oportunidades" em ocupações cortesãs ou a comercialização e a troca de mercadorias (ELIAS, 1994, p. 217). Desse modo, podemos observar que o surgimento das casas individuais se tornou um caminho para uma transição política. Gradativamente, em diversos lugares da Europa, o feudo entrou em decadência e um novo regime angariou autonomia, em grande medida, pois as cortes se tornaram um canal para a ascensão do Estado Absolutista.

Paulatinamente, as cortes cresceram, passando a estabelecer um "tipo de interligação, de dependência mútua entre as pessoas, que põe em movimento, por exemplo, processos de feudalização" (ELIAS, 1994, p. 195). O resultado foi uma maior conexão entre as cortes, estabelecendo um processo de divisão das funções sociais, pois um feudo tinha autonomia e pouco se comunicava com outros feudos. À medida que as cortes cresciam e desenvolviam suas relações de dependências, contribuíam para despontar o novo regime político. Para Elias (1994, p. 198),

quanto mais apertada se torna a teia de interdependências em que o
indivíduo está emaranhado, com o aumento da divisão de funções, maiores
são os espaços sociais por onde se estende essa rede, integrando-se em
unidades funcionais ou institucionais - mais ameaçada se torna a existência
social do indivíduo que dá expressão a impulsos e emoções espontâneas, e
maior a vantagem social daqueles capazes de moderar suas paixões, mais
fortemente é cada indivíduo controlado, desde sua tenra idade, para levar em
conta os efeitos de suas próprias ações ou de outras pessoas sobre uma série
inteira de elos na cadeia social em que os homens que residiam nestas
residências se distinguiam dos outros.

No processo de interdependência entre as cortes, segundo Elias (1994), as pessoas se tornavam mais comedidas, pois controlavam seus impulsos selvagens ao se distinguirem das demais. Nas cortes, as pessoas passavam por "uma transformação na economia das pulsões" (ELIAS, 1994, p. 217), controlando cada vez mais os seus comportamentos, a forma de comer, andar e se por à mesa. Podemos afirmar, assim, que os controles dos comportamentos sociais se traduziam em formas de violência simbólica, pois eram regulados por padrões de condutas sociais autocontroláveis e racionalizáveis.

Na interpretação de Norbert Elias (1994), a civilização e o Estado Absolutista se relacionavam, uma vez que a corte era a residência do rei. Com a centralização política, o rei passava a exibir o slogan "o Estado sou $E u$ ". Desse modo, ele tinha autonomia para controlar as pessoas que estavam no território sob o domínio do Estado Absolutista que foi conquistado por guerras. Também era exercida a violência física, ostentada pelos suplícios em praça 
pública, com o intuito de punir os infratores e evidenciar a autonomia soberana do Estado. Esperava-se que as pessoas tivessem medo e as infrações fossem reduzidas.

O Estado Nacional também exerceu controle social praticando a violência simbólica, uma vez que os suplícios foram substituídos pelas prisões. Paulatinamente, as técnicas de controles sociais se desenvolveram e foram usadas nas "fábricas/indústrias para controlar o tempo e o desempenho dos operários" (FOUCAULT, 1987, p. 79).

Gradativamente, essas técnicas de controle foram aprimoradas, de modo que, atualmente, sentimo-nos controlados e enclausurados pelo Estado Moderno e também pelo sistema capitalista, em que a privacidade se anula a cada dia em uma escalada da sociedade de controle preconizada por Foucault e pelos pós-estruturalistas.

Desse modo, a civilização começou a desenhar um novo cenário, na Europa, com o surgimento das cortes criadas pelos guerreiros cortesãos e com a formação dos burgos, ainda que a presença das tribos aldeãs fosse uma permanência. A civilização gradativamente configurou um novo cenário e representou o aperfeiçoamento das técnicas de controle social.

Naquele período, em toda a história da violência, esta era uma prática predominantemente masculina, pois os homens manifestavam fortemente sua virilidade com maior expressão entre a “idade dos 20 aos 29” (MUCHEMBLED, 2012, p. 7). Eles utilizavam armas brancas, provocando conflitos nas diversas tribos próximas à sua morada. Muchembled (2012, p. 13) identifica uma "agressividade predadora induzida pela necessidade de garantir a sobrevivência de sua espécie, inscrita nos genes caçadores masculinos em fecundar o máximo de parceiras". Paulatinamente, estas práticas, bem como os duelos entre guerreiros, seriam características de sociedades "selvagens", de acordo com os padrões estabelecidos pela civilização.

\section{VIOLÊNCIA NO ESTADO ABSOLUTISTA}

Gradativamente, quando as cortes ganharam mais forças e começaram a administrar os seus territórios, o Estado Absolutista começou a centralizar o direito de punir. Ele estruturou novas formas punitivas, que substituíram as exercidas entre parentes das vítimas que se sentiam ofendidas. A política absolutista definia os suplícios como a melhor forma de punir de forma exemplar e espetacular, como bem nota Foucault em Vigiar e Punir (1987). Paulatinamente, com a consolidação dos Estados Nacionais, os suplícios foram sendo substituídos pelas prisões modernas, em que as punições passaram a perder caráter espetacular, de acordo com a nova sensibilidade burguesa. 
Os suplícios estiveram presentes em toda a Europa e até mesmo nas monarquias tupiniquins. Eles eram espetáculos sanguinários, encenados em público. As pessoas vinham de lugares distantes para assistirem às execuções que duravam horas, conforme o relato a seguir:

Damiens fora condenado, a 2 de março de 1757, levado e acompanhado numa carroça, nu, de camisola, carregando uma tocha de cera de duas libras; [em seguida], na dita carroça, na Praça de Greve, e sobre um patíbulo que aí será erguido, atenazado no mamilos, braços, coxas e barrigas das pernas, sua mão direita segurando a faca com que cometeu o dito parricídio, queimada com fogo de enxofre, e às partes em que será atenazado se aplicarão chumbo derretido, óleo fervente, piche em fogo, cera e enxofre derretidos conjuntamente, e a seguir seu corpo será puxado e desmembrado por quatro cavalos e seus membros e corpo consumidos ao fogo, reduzidos a cinzas, e suas cinzas lançadas ao vento (FOUCAULT, 1987, p. 9)

Estas encenações sanguinárias chocavam pelas formas perversas das punições. Os criminosos eram comunicados das execuções com pouco tempo de antecedência. Os "crimes considerados inexpiáveis no século XVI e XVII eram os homicídios, infanticídios e parricídios”, com poucas chances de absolvição (MUCHEMBLED, 2012, p. 15).

De acordo com Foucault (1987, p. 56), "nas cerimônias de suplício, o personagem principal é o povo", e o objetivo era consolidar a moral do Estado, que ainda era frágil. Este intentava exercer controle sobre a população, pois esperava-se que, quando o povo assistia ao suplício, apaziguavam-se seus impulsos a cometer delitos semelhantes aos do supliciado. Os suplícios inibiam os crimes, todavia, não os exterminavam. Os suplícios foram abolidos pela pressão social, com a participação dos intelectuais do "Iluminismo que desqualificaram os suplícios reprovando-lhes as atrocidades" (FOUCAULT, 1987, p. 55).

Com a ruptura dos velhos padrões absolutistas e a transição para o Estado Moderno, os suplícios, gradativamente, foram substituídos pela punição moderna. A violência simbólica, paulatinamente, trocou de lugar com a física. Historicamente, esse fenômeno pode ser identificado na nova "redação dos códigos penais modernos: Rússia, 1769, Prússia, 1780, Pensilvânia e Toscana, 1786; Áustria, 1788; França, 1791, Ano IV, 1808 e 1810. Para a justiça penal, uma nova era" (FOUCAULT, 1987, p. 13). Cada nação construiu seu código específico de punição, em que cada pena passou a ser calculada em critérios como a gravidade do crime e o grau de periculosidade passada e futura do criminoso. Sendo assim, "não é mais o corpo a ser punido, mas, é a alma" (FOUCAULT, 1987, p. 21). Inclusive o código penal do Brasil têm suas origens nesse processo. 
No Estado Absolutista, a prática do crime ofendia o poder real, por isso a necessidade de punir em um espetáculo público. No Estado Moderno, o criminoso lesava a sociedade e e era processado e julgado por uma comitiva jurídica (perito, delegado, juiz, etc.). Assim, pretendia-se punir a moral do delituoso. Enquanto o regime absolutista eliminava o indivíduo transgressor, o Estado Moderno reconstituía a falha do sujeito, inserindo-o na prisão por um período em que o criminoso refletiria sobre seu erro. Depois de cumprida a pena, o sujeito voltaria, com a moral reestabelecida, para se ressocializar.

Para atingir os anseios de "Modernidade" e de um civilizado, foram desenvolvidos saberes científicos em diversas áreas, tais como: Medicina, Psicologia, História e Sociologia, que contribuíram para controlar os espaços sociais de forma racionalizada.

Concomitantemente às ciências, surgiram as instituições, que fragmentaram os espaços, exercendo disciplina sobre os sujeitos. Para Foucault, dessa forma, “o corpo está preso no interior de poderes muito apertados, que lhe impõem limitações, proibições ou obrigações [...], e ainda esquadrinha ao máximo o tempo, o espaço, os movimentos" (1987, p. 133). Na Modernidade, os sujeitos seriam moldados de acordo com os interesses dos Estados Nacionais Capitalistas, que tornavam seus corpos dóceis (FOUCAULT, 1987), adestrados pelas instituições sociais em que a disciplina estaria presente, exercendo pressões sobre os indivíduos, em todos os momentos.

Desde o século XIX, as instituições sociais, como "conventos, exércitos, fábricas, escolas, hospitais" (FOUCAULT, 1987, p. 133), desempenharam muito bem suas funções de controle social, de "a cada instante vigiar o comportamento de cada um, para sancioná-lo" (FOUCAULT, 1987, p.138). Os trabalhadores passaram a ser vigiados por sentinelas - tarefa que, no final do século XX, passou a cargo das câmeras, dispostas em quase todos os espaços sociais. Gradativamente, o Estado Moderno evoluiu suas técnicas de vigiar e disciplinar os indivíduos, controlando as ações por dispositivos que atualmente estão disseminados por toda a sociedade.

\section{BRASIL: UMA SOCIEDADE VIOLENTA}

A violência que se configura no Brasil, atualmente, é fruto do processo histórico e tem suas origens na colonização. Portugal, com sua política expansionista, "no século XIV dominava o comércio marítimo na Ásia e África. Logo no início do século XV estabeleceu os primeiros contatos de dominação com os ameríndios na América" (VIEIRA, 2009, p. 7). Iniciou-se, assim, a colonização em moldes violentos, e a grande maioria do povo brasileiro, 
hoje, herdou essa história violenta, refletindo-a no seu cotidiano marcado pela desigualdade social.

O processo de colonização que subjugou os autóctones por séculos teve a contribuição da Igreja católica ibérica (HANSEN, 1998), que tinha por objetivo cristianizar os povos que não compartilhavam dos códigos culturais dos ocidentais, como os indígenas. Essa política se estabeleceu de forma distinta em vários períodos. No contexto em que o Brasil era colônia de Portugal, a prática de catequização dos indígenas foi desenvolvida pelos jesuítas, os quais tinham autonomia para fazê-lo, e depois, no Império, foi praticada pelos capuchinhos sob a égide do Estado Imperial.

Essa política católica sustentou de forma contundente a colonização do Brasil, espoliando as terras dos ameríndios por "meio da 'guerra justa' promovida pela Coroa portuguesa contra os indígenas da sua colônia brasileira nos séculos XVI e XVII" (HANSEN, 2001, p. 74). Assim, os ameríndios foram submetidos ao processo de catequização, civilização e progresso, o que permitiu ao colonizador recrutá-los e reduzi-los em aldeamentos, tomando posse das suas terras. Essa política de dominação prosseguiu no período do Império. A colonização dos ameríndios durou séculos, no Brasil, sendo subsidiada pela jurisdição com inúmeras leis que a tornaram legal, encurralando as pessoas e esquadrinhando as terras indígenas.

Os ameríndios foram aglutinados nos aldeamentos, permitindo ao colonizador assaltar as terras indígenas com bases legais, auxiliado pela participação dos religiosos católicos. Regra geral, a violência empregada contra o indígena na espoliação das suas terras ocorreu de forma desumana, e a maioria das reservas indígenas remanescentes estão reduzidas, quando não à mercê de latifundiários que almejam expropriá-las.

A violência que se processou pelo colonizador em relação ao indígena foi estrondosa, e os conflitos gerados em decorrência desse processo foram intensos. Em decorrência da não aceitação dos ameríndios dos padrões culturais impostos pelos colonizadores a eles, grosso modo, o colonizador espoliou as terras indígenas, mas não os civilizou, como podemos perceber na seguinte citação:

A educação religiosa he exigência necessária, mas este deve seguir e não procede a educação civil, a relação dos Índios como foi praticada pelos Jesuítas certamente não conseguiu dominar. A experiência tem mostrado isso, desde aquelles Religiosos Jesuítas que deixarão alguns indígenas nos Mattos de Guaíra que na ocasião da sua expulsão pelos Paulistas, tomarão outra vez os seus costumes, e em poucos annos ficaram tão selvagens como erão os seus antepassados antes do descobrimento do Brasil e para saber o que buscou o Estado com essa civilização Jesuítica basta ponderar que 
duzentos annos de Cathetequese e Redução nunca sahiu hum cidadão útil (CIMITILI, 2007, p. 2).

Este fragmento narra a resistência indígena à civilização, narrativa que remonta ao século XIX, redigida pelo Governo Imperial nos relatórios de correspondência entre o Governo e o aldeamento de São Jerônimo da Serra (PR). Nele, o funcionário do aldeamento afirma que nem as Reduções Jesuíticas, nem os aldeamentos do século XIX civilizaram um indígena durante duzentos anos de colonização.

Não podemos negar que os indígenas tiveram suas terras dominadas, tendo sido aglutinados nos aldeamentos. No entanto, a civilização praticada há séculos, inserida por distintas políticas indigenistas ainda no período da Colônia, como também no Império, foi rejeitada pelos indígenas, pois eles tinham seus princípios culturais, desenvolvidos há séculos, aos quais seguiam. Em suma, podemos afirmar que os indígenas tiveram, quase que de forma integral, suas terras espoliadas, no entanto, resistiram ao processo de colonização.

A violência que se manifesta no cotidiano dos brasileiros, atualmente, tem a sua origem nas relações sociais estabelecidas pelos colonizadores em detrimento dos indígenas, africanos, judeus e brancos pobres no período em que o Brasil era colônia de Portugal.

Durante a colonização, "milhares de africanos extraídos da África foram trasladados para o Brasil com a escravidão" (SIQUEIRA, 2010, p. 137). Após séculos, essa prática desumana imposta ao africano chegou ao fim, formalmente, nos findos do século XIX, e o trabalho escravo foi substituído pela mão de obra do imigrante. A partir de então, um novo cenário se delineou.

Com o final da escravidão e a transição do Império para República, determinada classe social do Brasil aspirava por princípios de progresso, industrialização e construção da nação. Dessa forma, os africanos libertos, na concepção da elite, não contemplavam as características que impulsionariam o Brasil ao progresso, tornando-se um problema social.

Essa questão foi discutida pelos políticos, no final do século XIX, contexto em que "havia um claro consenso entre os deputados de que Abolição trazia consigo os contornos do fantasma da desordem" (CHALHOUB, 2001, p. 66). Os africanos foram escravizados legalmente pelos não indígenas no período da Colônia e do Império. Ademais, quando a escravidão não se encaixava no contexto social vigente, sendo extinguida pelas transições políticas socioeconômicas internas e externas, eles, que antes eram úteis com a sua força de trabalho escravo, depois de libertos, tornaram-se um problema para a elite, que desejava construir um Brasil com uma população predominantemente branca. 
No entanto, as dificuldades para a elite construir um Brasil sobre esses ideais não foram pequenas. Os problemas acumulados historicamente com a colonização não desapareceriam de forma mágica no período da República.

Interpretamos que o desejo de dominação da elite, manifestada em todos os períodos, criou inúmeros problemas sociais que, gradativamente, acumularam-se, tais como a concentração de riqueza, a desigualdade social, a miséria e a criminalidade, problemas engendrados em grande medida pela elite, a qual atribuiu a responsabilidade sobre tais situações à população.

Assim, no final do século XIX, o Brasil estava passando por um processo de transição política em que a elite pretendia inseri-lo ao regime capitalista industrial que estava em ascensão na Europa. No entanto, os problemas sociais criados pela colonização ficaram explícitos e foram atribuídos à população pobre, negra e mestiça que, além de ter sido dominada por um seleto grupo social, ainda foi responsabilizada pelos problemas criados pela minoria social.

No início da República, a ordem que se estabelecia era a "capitalista" (HANSEN, 2001. p. 62), que tinha por objetivo levar o Brasil ao "progresso" e construir, na população, a ideologia do "amor ao trabalho, independente das vantagens materiais que possam daí advir" (HANSEN, 2001, p. 69). Isto é, não importava se os problemas sociais ainda se agravassem, a ordem que se processava, desde o período do Império, era construir a moral do trabalho na população, de forma que ele fosse valorizado, pois esta era a ideologia que sustentava o capitalismo, que ganhou forças com a "Revolução Industrial que todos deveriam seguir. Disseminada por múltiplos países, inclusive o Brasil” (SIQUEIRA, 2010, p. 138).

A industrialização, no início da República, era bem insipiente, começando a ser inserida, no Brasil, com mais força na década de 30 do século XX. Nesse contexto, os empregos que existiam no setor, em inícios do regime republicano, eram destinados aos brancos com situação econômica mais favorável. Desse modo, os negros, após o fim da, escravidão não foram absorvidos nos espaços produtivos, ficando à margem da sociedade, que despontava para os princípios capitalistas, como a valorização do trabalho que beneficiou o imigrante europeu.

Os negros, ao serem excluídos, organizavam-se em espaços que não ofereciam condições dignas de sobrevivência, como nos então cognominados "cortiços, favelas e morros no final do século XIX e início do XX” (SIQUEIRA, 2010, p 144). Esses espaços abrigavam os pobres e imigrantes que não dispunham de condições econômicas para se alocarem em 
casas confortáveis. Gradativamente, a nação do Brasil, que, desde o contexto do Império, foi pensada nos princípios de civilização e progresso, foi construída e reservada a grupos seletos.

A concentração das pessoas em pontos específicos resultou em novos problemas sociais para a bancada elitista, que passou a compreender a "classe pobre" como as "classes perigosas". Os pobres representavam para a elite "tendência à ociosidade, propensão a vícios, povos sem moralidade e que poderiam facilmente rolar até o abismo do crime" (CHALHOUB, 2001, p. 76). Desse modo, observamos que os problemas produzidos pela elite foram atribuídos à população descendente de um processo de subjugamento da colonização administrada pelo Império, que, no final do século XIX, havia passado por uma transição política cognominada como republicana e que pretendia ser capitalista.

O capitalismo projetava seus tentáculos de dominação, mas não favorecia a todos. Dessa forma, é

Ilusório pensar que esse mercado absorve todos os indivíduos. [...] Este esquema não dá conta dos milhares dos indivíduos que, não conseguindo se tornar trabalhadores assalariados sobreviviam sem se integrarem ao "tal" mercado, mantendo-se como ambulantes, vendedores de jogo de bicho, mendigos, biscateiros, etc. (CHALHOUB, 2001, p. 55).

No final do século XIX, o Brasil ainda era agrário e contava com pouquíssimas indústrias, mas pretendia se inserir ao mercado capitalista. Com estas características, as oportunidades de trabalhos eram poucas, e as que existiam eram altamente disputadas entre os imigrantes e, em alguns momentos, também pelos recém libertos.

Sidney Chalhoub (2001) escreve sobre o cotidiano interétnico que se estabeleceu de forma conflituosa no Rio de Janeiro, retratado em sua obra Trabalho, Lar e Botequim: o cotidiano dos trabalhadores no Rio de Janeiro da belle époque, tendo como fontes os processos criminais. Desse modo, podemos observar a violência simbólica praticada pela elite em detrimento da população, que resultou na produção de conflitos entre as distintas etnias na busca por um emprego. Os imigrantes europeus foram os mais privilegiados se os compararmos com os indígenas e os africanos.

No entanto, a violência não deixou de ser praticada, pois eles viviam em "péssimas condições e também se sujeitavam na disputa por vagas de trabalhos, e quando preenchidas eram de baixa remuneração" (SILVA, 2010, p. 10) e, em muitos casos, acabavam contraindo dívidas impagáveis com os patrões.

É notório que a construção do Brasil tem sua gênese pautada na violência, sendo visíveis as "parcialidades históricas de um país estruturado pelo regime de trabalho escravo" 
(CORRÊA, 2013, p. 58). Some-se a isso o subjugamento de muitas etnias originárias, os indígenas, que tiveram quase que integralmente suas terras expropriadas, processo que gradativamente resultou na concentração de terras em mãos de uma minoria.

Dessa forma, a sociedade brasileira tornou-se extremamente hierarquizada, predominando uma enorme concentração de riqueza, principalmente, derivada da posse de terras. Como resultado desse processo, a renda se concentra na elite, que impede o acesso à educação e aos outros direitos sociais à maioria da população menos favorecida, citem-se os povos tradicionais, indígenas, quilombolas, faxinalenses e, pulverizado etre essa grande maioria, o pobre trabalhador escravo do século XXI, o qual sobrevive com um alário mínimo em um cenário político no qual as perspectivas de melhorias sociais ficam ainda mais reduzidas.

Estas práticas produziram e cristalizaram um país violento. A desigualdade socioeconômica entre as pessoas é nítida, fator determinante para a produção da violência. Esta disparidade foi construída pela exclusão social durante o processo histórico. A violência foi engendrada no cotidiano, nas práticas sociais, marcadas, por exemplo, por conflitos gerados entre ex-escravos e imigrantes no final do século XIX e no início do XX.

A construção dessa realidade violenta do Brasil também pode ser estudada por meio dos processos criminais, que são fontes profícuas. Tais documentos passaram a ser mais utilizados pelos historiadores brasileiros na década de 1980, conforme destaca Grimberg (2009, p. 125):

1980 [...] como base documental para trabalhos sobre criminologia. Mas foi nesse período que o seu uso se generalizou em diversas abordagens históricas e antropológicas, da História Colonial à Republicana. Para citar apenas três leituras obrigatórias para todos os que pretendem se iniciar no tema, foi em 1984 que Boris Fausto publicou seu Crime e cotidiano; em 1986, saiu Trabalho, lar e botequim, de Sidney Chalhoub, e, no ano seguinte, Crime e escravidão, de Maria Helena Machado.

Os processos criminais contêm histórias do cotidiano dos afrodescendentes, indígenas e imigrantes. Os processos permitem que o historiador ouça as vozes de pessoas comuns e possa inferir sobre sua participação na história nacional.

André Rosemberg e Luis Antônio Francisco SOUZA, no artigo Notas sobre o uso de documentos judiciais e políticas como fontes de pesquisa histórica, sobre autores que são contrários à utilização dos processos criminais como fontes, destacam a argumentação de Ivone Maggie. Ela reflete que “o juiz julga o que está nos autos e não o que se passou na verdade. Portanto, o que está nos autos não pode ser levado em consideração. O processo 
refere-se, àquilo que contém" (ROSEMBERG; SOUZA, 2009, p. 164). Ou seja, de acordo com Maggie, um processo não revela todo um fato ocorrido no real, pois podem existir várias versões ocultas, e, dessa forma, segundo ela, o processo criminal não expressa a integridade do acontecimento, não podendo ser considerada uma fonte confiável.

Ao contrário, Rosemberg e Silva (2009) afirmam que os processos tornam possíveis estudos de histórias ainda não reveladas. Segundo eles, existem vários discursos sobre determinado acontecimento, muitas vezes versões "fragmentadas, como feixes de vários documentos autônomos e muitas vezes independentes. No processo-crime, existem pluralidades de vozes que se cruzam, se esbarram e se complementam num mesmo processo" (ROSEMBERG; SILVA, 2009, p. 168), as quais precisam ser interpretadas por meio de uma metodologia.

Esses documentos não se equivalem às fontes oficiais depositadas nos arquivos? Qualquer fonte precisa passar pelo crivo de análises e interpretações das informações que ela pode oferecer.

Os processos criminais auxiliam, por exemplo, na compreensão das transformações sociais que ocorreram no Brasil no século XIX, como a transição do regime Imperial para o Republicano, dos conflitos com o fim da escravidão, a inserção do imigrante e a exclusão do negro e do conflito entre as etnias que disputavam os espaços sociais no início da República (CHALHOUB, 2001). Também contribui para se compreender o processo de consolidação do Brasil como Estado moderno: era necessário caracterizá-lo como nação, construir um espírito patriótico, portador de uma identidade nacional. Seria necessário, assim, construir um sentimento de prestígio ao trabalho que sempre fora desprestigiado por ser realizado por escravos.

Assim, para compor a ética do trabalho e a identidade nacional, foram selecionadas algumas etnias, que, supostamente, compreendiam os padrões elegidos para a construção da nação, ou seja, consideradas etnias brancas.

Estas questões ideológicas e raciais repercutiram entre as etnias, gerando preconceito e segregação entre negros e brancos. Assim, no

Rio de Janeiro ao longo do século XIX e da Primeira República é não menos relevante para o fato de que essas rivalidades nacionais e raciais são reativas e até reelaboradas pela classe trabalhadora dentro do contexto mais amplo da transição para a ordem burguesa na cidade no período pós-abolição (CHAULHOUB, 2001, p. 61). 
Estas rivalidades étnicas aconteceram, em grande medida, pela falta de vagas no mercado de trabalho. Para Eulalia M. L. Lobo, "a abolição da escravatura liberou mão de obra do campo para a cidade, formando-se um mercado de trabalho com superabundância" (CHAULHOUB, 2001 p. 61), somado ainda com levas de distintas etnias europeias, que chegaram ao Brasil para a efetivação do projeto do governo de inserir a população branca no território brasileiro.

As vagas no mercado de trabalho eram escassas, pois a economia sentia os reflexos do período escravocrata, em que a industrialização não havia estabelecido redes profícuas. Isso gerou disputas e rivalidades entre as distintas etnias no Brasil.

O caso do Rio de Janeiro, por meio da análise de processos criminais, permite-nos compreender o estabelecimento das rivalidades étnicas que tornaram o cotidiano conflituoso e, na maioria das vezes, racista por parte dos imigrantes em relação aos afrodescendentes, como podemos perceber no excerto a seguir:

Um dos depoentes, Antônio José Teixeira, natural da capital federal, de 20 anos, solteiro, industrial, declara que é o encarregado gerente, da olaria da rua Capitão Félix número um e por isso é que se encarregava da administração da mesma olaria. Que entre oito empregados para o serviço teve um nacional de cor preta de nome Ramiro Costa e que pelo mau procedimento do mesmo e do gênio alterado teve necessidade de despedi-lo do serviço isso há oito dias mais ou menos. Que, ontem, às nove horas mais ou menos, ele declarante achava-se na olaria e viu quando alguns dos empregados chegavam da rua para se recolher, e ao entrarem no portão, o mesmo Ramiro Costa, que se achava do lado de fora do portão agrediu aos mesmos empregados, armado com um fueiro de carroça, e em seguida com um revólver que trazia disparou dois ou três tiros, atingidos ao empregado Germano José Pinto, que ficou ferido (CHALHOUB, 2001, p. 90).

Com a narração desse processo criminal, podemos perceber que o conflito nascera no espaço de uma olaria e terminou adjacente a ela, e que quase todos os empregados eram brancos, exceto Ramiro, de cor preta. Dessa forma, os empregados brancos acusaram Ramiro de promover conflitos no trabalho, conforme narração de Chalhoub (2001, p. 90): "todos condenam a conduta de Ramiro, que tinha maus instintos e era muito desordeiro". Com essa afirmativa, é possível presumir que houve conspiração contra Ramiro, que era negro. Os empregados brancos usavam discursos provocativos, que deixaram Ramiro nervoso, e este, em um momento exaltado, atirou contra um empregado branco. Esse motivo o levou à demissão, deixando a sua vaga livre para outro imigrante ocupá-la.

Por meio dessas minúsculas práticas cotidianas, a nação brasileira se consolidava como moderna, assumindo características das nações europeias, compostas por populações 
brancas. Solidificava-se, dessa forma, uma ideologia racista contra os afrodescendentes, perceptível mesmo após mais de cem anos de abolição da escravatura.

Os estudos com os processos criminais, a exemplo de Trabalho, lar e botequim, que citamos aqui, permitem-nos entender que o Brasil foi moldado por caminhos violentos identificados na última metade do século XIX. Obviamente, a violência, não se encerrou naquele período, mas continua presente nas sucessivas fases da construção do Brasil na República ${ }^{1}$.

A sociedade brasileira foi construída em moldes violentos nas várias instâncias sociais. A violência também é diluída no cotidiano e agravada pela má administração política.

Marcondes Filho (2001, p. 21) identificou a violência no Brasil como cultura:

tradicionalmente herdada, com raízes na sociedade escravocrata, no tipo colonizador que aqui se instalou e na transposição de práticas persecutórias e perversas da metrópole, realizando-se, no século XX, por meio de traços marcadamente típicos de nação de periferia do capitalismo.

Isto é, em um primeiro momento, o Brasil foi construído por vários acontecimentos violentos ocorridos ao longo da colonização. A política de modernização liberal e neoliberal produziu espaços ainda mais violentos, engendrados pela concentração de capital em alguns países, como Inglaterra, França, Estados Unidos, Japão, Suíça, etc. Sendo assim, grande parcela dos países da África e da América Latina sofreram as ações excludentes do capital.

Em um processo contraditório, o capital construiu regiões subdesenvolvidas, gerando desigualdade social e produzindo violência, resultado, em grande medida, do medo coletivo da falta de emprego. A violência se disseminou; basta mencionar, como prova disso, o pavor de ser assaltado na sua residência. De modo geral, esses fatores, produzem o sentimento de instabilidade.

Segundo Marcondes Filho (2001), o capital asseverou, nos países desenvolvidos, os espaços de exclusões sociais, produzindo inúmeras regiões violentas, consolidando a cultura da violência em nosso país.

\footnotetext{
${ }^{1} \mathrm{O}$ Estado republicano iniciou seu regime pelos militares, seguidos pela política do café com leite, que restringiu as decisões a São Paulo e Minas Gerais, excluindo as outras regiões da nação do cenário administrativo. Getúlio Vargas chegou ao poder por meios conflituosos, rompendo a política do café com leite. Seu mandato, de 1930 a 1945, também conferiu características e práticas violentas. Após essas fases, a política ganhou princípios democráticos que sobreviveram até a tomada do poder pelos militares, em 1964, quando muitos críticos e intelectuais foram reprimidos, mortos e exilados, havendo uma reabertura para a democracia em 1985.
} 
Dessa forma, multiplicaram-se os espaços da violência, com maior intensidade, nas regiões periféricas das capitais. Fato que ocorre em quase todo o Brasil, inclusive nas pequenas cidades, ou ainda no trânsito, que é moldado por práticas violentas e se tornou um lugar de

agressividade motorizada realiza materialmente a violência da fundadora cultura brasileira nos expedientes de exclusão e autoimposição violenta nas pistas, nos gestos agressivos, nas fechadas, no total desaparecimento das regras de respeitabilidade e convivialidade. Exerce-se aqui uma violência através da velocidade (MARCONDES FILHO, 2001, p. 24).

O trânsito é uma máquina de produzir vítimas. A modernização impetrada pela potência e velocidade dos veículos, no século $\mathrm{XX}$, gerenciados pela impaciência e intolerâncias dos condutores, tornaram as estradas cenários violentos, em que milhares de pessoas deixam suas vidas, em parcelas no cotidiano e, principalmente, nos feriados, caracterizando esta violência de "hard",2 na concepção de Marcondes Filho (2001).

Em suma, a violência pode ser caracterizada de forma física ou simbólica e esteve presente em todos os períodos históricos, abrangendo todas as dimensões sociais, até mesmo as práticas do cotidiano. Com o processo de maior conexão entre as sociedades, a violência se intensificou pelo desejo de dominação, levando os homens a projetarem a possibilidade de destruição do planeta terra.

\section{CONSIDERAÇÕES FINAIS}

Estudos sobre violência propiciam compreender que ela é um componente histórico das distintas sociedades em diferentes temporalidades. Evidenciamos, assim, neste trabalho, a constante de que as sociedades foram moldadas pelo estabelecimento da violência.

$\mathrm{Na}$ Antiguidade, era comum o sacrifício ritual. Também apresentamos a violência utilizada pelos senhores feudais na organização e manutenção dos feudos. Analisamos a construção dos Estados Absolutistas, que celebravam rituais sanguinários, por meio dos suplícios, que, em uma fase posterior, confluíram nos Estados Modernos, controlando a sociedade de forma racional, produzindo mecanismos de autocontroles sociais.

O Brasil esteve imbuído nesse processo de transformações, pautado na violência, nas transições dos vários regimes políticos, bem como na passagem do Império para o Estado

\footnotetext{
${ }^{2}$ Marcondes Filho usou a expressão hard, em seu trabalho Violência fundadora e violência reativa na cultura brasileira (2001), como forma de caracterizar a violência que é estabelecida de forma física.
} 
republicano. Os resultados das transmutações engendram a cultura da violência abordada por Marcondes Filho (2001), produzindo o medo coletivo da criminalidade e do desemprego.

Portanto, a violência, seja administrada em grandes doses ou em minúsculas porções, está disseminada no cotidiano. Embora a violência tenha se caracterizado de distintas formas, em cada temporalidade, atualmente, ela está presente de modo intenso. O capital é o grande propulsor da violência e engendra vários caminhos de dominação que estão assolando o planeta, causando instabilidade e medo coletivo. Resta-nos um questionamento: será que o planeta sobreviverá ao violento século XXI?

\section{REFERÊNCIAS}

CIMITILE, Luiz. Catálogo Seletivo de Documentos Referentes aos Indígenas no Paraná Provincial: 1853-1870. Curitiba: Imprensa Oficial, 2007. Disponível em: <http://www.arquivopublico.pr.gov.br/arquivos/File/pdf/catalogo_indigena_L.pdf>. Acesso em: 2001.

CHALHOUB, S. Trabalho, lar e botequim: o cotidiano dos trabalhadores no Rio de Janeiro da belle èpoque. 2. ed. São Paulo: Editora da UNICAMP, 2001.

CORRÊA, M. Trabalho Escravo. São Paulo: Brasiliense.

ELIAS, N. Sugestão para uma teoria de processos civilizadores. In: O Processor civilizador. 2 ed. Rio de Janeiro: Jorge Zahar Ed, 1994. p. 192-297.

FOUCAULT, Michel. Vigiar e punir: o nascimento da prisão. Petrópolis: Vozes, 1987.

GIRARD, R. A violência e o sagrado. São Paulo: UNESP, 1990.

GRINBERG, K. A história nos porões dos arquivos judiciários. In: PINSKY, Carla Bassanezi; LUCA, Tania Regina de (Org.). O historiador e suas fontes. São Paulo: Contexto, 2009.

HANSEN, Antônio A. História da Companhia de Jesus. Petrópolis: Vozes, 2001.

MARCONDES FILHO, C. Violência fundadora e violência reativa na cultura brasileira. São Paulo em perspectiva, São Paulo, v. 15, n. 2, p. 20-27, 2001.

MUCHEMBLED, R. História da violência: do fim da Idade Média aos nossos dias. Rio de Janeiro: Forense Universitária, 2012.

ROSEMBERG, A.; SOUZA, Luis Antônio Francisco. Notas sobre o uso de documentos judiciais e policiais como fonte de pesquisa histórica. UNESP - FCLAs - CEDAP, v. 5, n. 2, p. 159-193, dez. 2009.

SILVA, A. Exploração do Trabalho. São Paulo: Brasiliense, 2010. 
SIQUEIRA, Manoel. O Trabalho Escravo. Ver. Trib. Trab. $2^{a}$ Reg., Belo Horizonte, v. 52, n. 82, p. 128-149, jul/dez. 2010.

VIEIRA, Marcelo. A Colonização Portuguesa no Brasil e a Propriedade. Niterói: Universidade Federal Fluminense, 2009.

ARTIGO ENVIADO EM: 31/05/2016

ARTIGO ACEITO PARA PUBLICAÇÃO EM: 13/12/2016 